\title{
RELATIONSHIP BETWEEN CELL MORPHOLOGY AND THE TYPES OF DIAMINOPIMELIC ACID IN KITASATOSPORIA SETALBA
}

\author{
YŌKO TAKAHASHI, YUZURU IWAI AND SATOSHI ŌMURA \\ The Kitasato Institute and Kitasato University, \\ 5-9-1, Shirokane, Minato-ku, Tokyo 108, Japan
}

(Received August 25, 1983)

\begin{abstract}
The relationship between cell morphology and the type of 2,6-diaminopimelic acid $\left(\mathrm{A}_{2} \mathrm{pm}\right)$ in Kitasatosporia setalba was studied in a submerged culture. When a strain of $K$. setalba was cultivated in a liquid culture with shaking, it produced two kinds of cells, spore-like cells and filamentous mycelia, which are morphologically distinct from each other. The former contained LL-A $\mathrm{A}_{2} \mathrm{pm}$, and the latter meso- $\mathrm{A}_{2} \mathrm{pm}$. A time course study in a submerged culture inoculated with the spore-like cells demonstrated that each type of $\mathrm{A}_{2} \mathrm{pm}$ detected in $K$. setalba is clearly associated with one of the two forms of cell.
\end{abstract}

A soil isolate, strain KM-6054, produces the new antibiotic setamycin which is active against trichomonads and gram-positive bacteria (1). The morphological and cultural characteristics of the strain resemble those of strains of the genus Streptomyces when grown on agar media. However, strain KM-6054 could not be classified in any of the known genera of the order Actinomycetales, because the cell wall type (2), which is one of the most important criteria in the classification of genera of actinomycetes, was a new one containing both LL- and meso-2, 6diaminopimelic acid $\left(\mathrm{A}_{2} \mathrm{pm}\right)$ as well as glycine and galactose. The strain was fully characterized and determined to belong to a new genus, for which the name Kitasatosporia has been proposed and the type species of Kitasatosporia is Kitasatosporia setalba ŌMURA, TAKAHASHI, IWAi and TANAKa (3).

We reported that different isomers of $\mathrm{A}_{2} \mathrm{pm}$ were detected separately in aerial and in vegetative mycelia of $K$. setalba grown on an agar medium: the former contains LL- $\mathrm{A}_{2} \mathrm{pm}$, while the latter contains meso- $\mathrm{A}_{2} \mathrm{pm}$ as the main component (4). In a further study with a submerged culture of $K$. setalba, spore-like cells and filamentous mycelia, were observed, which are morphologically distinguishable from each other. It was of interest to determine whether the cell types contain different two kinds of $\mathrm{A}_{2} \mathrm{pm}$. In fact LL- $\mathrm{A}_{2} \mathrm{pm}$ is contained in the spore-like cells, while mainly meso- $\mathrm{A}_{2} \mathrm{pm}$ is contained in the filamentous mycelia. 


\section{MATERIALS AND METHODS}

Actinomycete strains. K. setalba was isolated from a soil sample collected at Setagaya-ku, Tokyo. Strain KM-6054 (ATCC 33774, IFO 14216), the type strain of K. setalba, and two reference strains, Streptomyces albus KA-1023 and Nocardia asteroides KB-76 were used. The cultures were maintained on inorganic salt-starch agar.

Separation of spore-like cells and filamentous mycelia. A loopful of the aerial mycelia of strain KM-6054 was transferred into $100 \mathrm{ml}$ of Y-D medium consisting of $1 \%$ yeast extract (Difco) and $1 \%$ glucose in a 500-ml Sakaguchi flask and incubated on a reciprocal shaker at $27^{\circ}$ for 3 days. The culture was filtered through a Toyo Roshi No. 1 filter. The residue was washed with water to give filamentous mycelia. Spore-like cells were obtained by centrifugation $(2,940 \times g$, $20 \mathrm{~min}$ ) of the filtrate. Purity of the cell preparations was confirmed by microscopic observation.

Whole-cell preparations. The whole mycelia were harvested by centrifugation $(2,940 \times g, 20 \mathrm{~min})$ of the submerged culture in Y-D medium, and thoroughly washed with water. The washed mycelia were used as a whole-cell preparation after treatment with ethanol and drying at room temperature.

Time-course study in a submerged culture. The spore-like cells, obtained by filtration under sterile conditions, were inoculated into $100 \mathrm{ml}$ of Y-D medium in a $500-\mathrm{ml}$ Sakaguchi flask and incubated at $27^{\circ}$ on a shaker. Portions of the culture were taken at intervals, and the whole mycelia were analyzed for the contents of two kinds of $\mathrm{A}_{2} \mathrm{pm}$, and their growth and morphology were observed by photo- and electron-microscopy. Growth was expressed in terms of dry weight of cells prepared by drying the washed mycelia at $60^{\circ}$.

Analysis of $A_{2} \mathrm{pm}$. Ten $\mathrm{mg}$ of dried cells was hydrolyzed in $6 \mathrm{~N} \mathrm{HCl}$ at $100^{\circ}$ for $18 \mathrm{hr}$, and then analyzed for $\mathrm{A}_{2} \mathrm{pm}$ by thin-layer chromatography on cellulose (Avicel SF-2020, Funakoshi Yakuhin Co.), developed with methanolpyridine-10 $\mathrm{N} \mathrm{HCl}-\mathrm{H}_{2} \mathrm{O}(32: 4: 1: 7)$ and detected with ninhydrin. Quantitative analysis of $\mathrm{A}_{2} \mathrm{pm}$ was carried out with a TLC scanner (Model CS-920, Shimadzu) at $410 \mathrm{~nm}$.

Photo- and electron-microscopy. The morphology of the strain was observed with a light microscope (Vanox, Olympus) and a scanning electron microscope (Model S-430, Hitachi). The samples were prepared from the washed cells stained with Pfeiffer's solution for light microscopy and with osmium-vapor fixation for scanning electron microscopy.

\section{RESULTS}

Since it is noteworthy that $K$. setalba contains two kinds of $\mathrm{A}_{2} \mathrm{pm}$ as constituents of the cell wall, we studied the relationship between morphology and the $\mathrm{A}_{2} \mathrm{pm}$ type in the cells grown in liquid media. Figure 1 is a photomicrograph of 


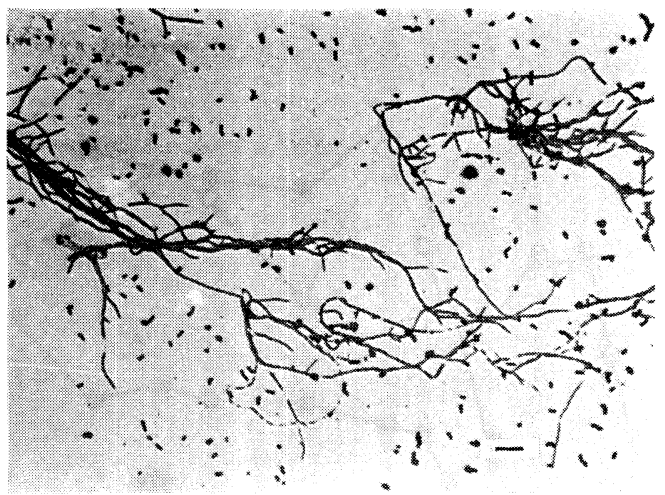

Fig. 1. Photomicrograph of $K$. setalba grown in a submerged culture in Y-D medium for 3 days.

The bar marker represents $10 \mu \mathrm{m}$.

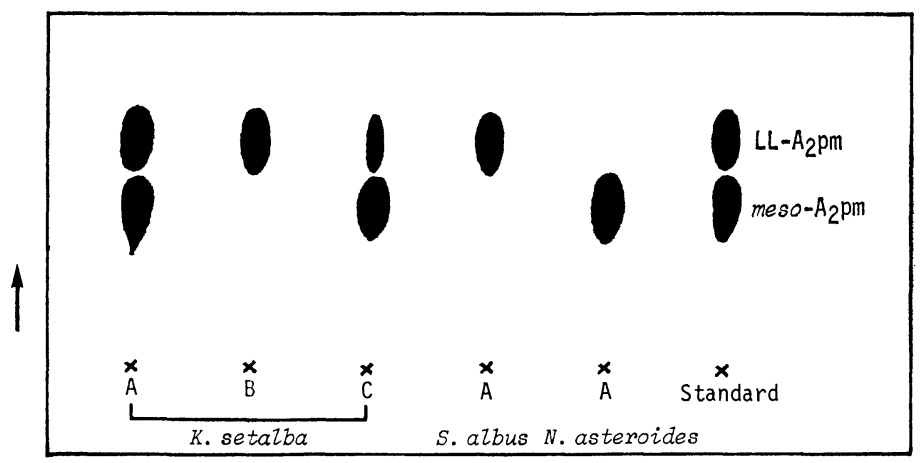

Fig. 2. Thin-layer chromatogram of $A_{2}$ pm in whole cells (A), spore-like cells (B) and filamentous mycelia (C) of $K$. setalba grown in a submerged culture.

$S$. albus and N. asteroides were used as reference organisms. Thin-layer chromatography on cellulose was developed with methanol-pyridine- $10 \mathrm{~N} \mathrm{HCl}_{-} \mathrm{H}_{2} \mathrm{O}(32: 4: 1: 7)$ and detected with ninhydrin.

mycelia grown in a liquid culture with shaking at $27^{\circ}$ for 3 days. K. setalba was found to develop filamentous mycelia and spore-like cells, which are morphologically distinguishable from each other and can be effectively separated by filtration with a Toyo Roshi No. 1 filter. The $\mathrm{A}_{2} \mathrm{pm}$ analysis revealed that the spore-like cells contain only $\mathrm{LL}_{-} \mathrm{A}_{2} \mathrm{pm}$ and the filamentous mycelia contain mostly meso$\mathrm{A}_{2}$ pm (Fig. 2). S. albus and N. asteroides, the reference organisms, contained only LL-A $\mathrm{A}_{2} \mathrm{pm}$ and meso-A $\mathrm{A}_{2} \mathrm{pm}$, respectively.

To confirm the above observations and to investigate morphological changes in $K$. setalba in submerged cultures, time course studies were carried out. As shown in Fig. 3, only LL-A $\mathrm{A}_{2} \mathrm{pm}$ was detected at $0 \mathrm{hr}$, because only spore-like cells containing LL- $\mathrm{A}_{2} \mathrm{pm}$ were inoculated as seed culture. Mainly meso- $\mathrm{A}_{2} \mathrm{pm}$ 


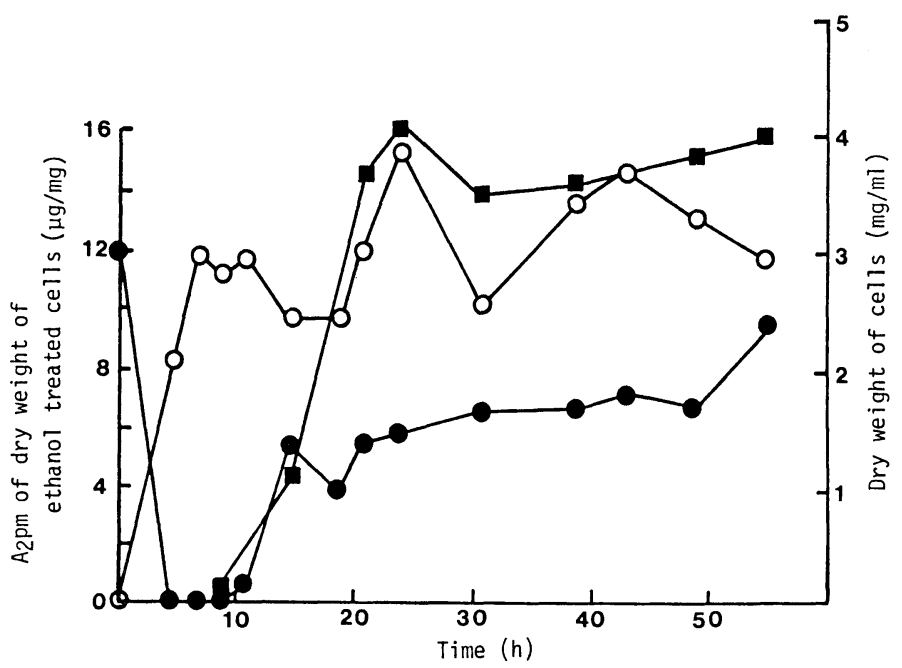

Fig. 3. Time course of $\mathrm{LL}-$ and meso- $\mathrm{A}_{2} \mathrm{pm}$ contents in the whole cells of $K$. setalba grown in a submerged culture.

Spore-like cells only were inoculated into $100 \mathrm{ml}$ of $\mathrm{Y}$-D medium in a $500-\mathrm{ml}$ Sakaguchi flask and incubated at $27^{\circ}$ with shaking.

Whole broth was withdrawn at intervals to determine the levels of LL- (0) and meso-A_pm $(\mathcal{C})$, and the dry weight of cells $(\mathbf{\square})$.

was detected during $5-11 \mathrm{hr}$ of incubation. After $11 \mathrm{hr} \quad \mathrm{LL}_{-} \mathrm{A}_{2} \mathrm{pm}$ increased rapidly. Similar amounts of LL- and meso-A $\mathrm{Am}_{2}$ were detected after $50 \mathrm{hr}$ of incubation.

Since the most significant changes in the levels of LL- and meso- $\mathrm{A}_{2} \mathrm{pm}$ were observed during the first $24 \mathrm{hr}$ (Fig. 3), the morphological changes were also observed during this period. Figures 4 and 5 show the photomicrographs and scanning electron micrographs of $K$. setalba grown in a liquid culture. The spore-like cells transferred as a seed culture began to elongate in one hr (Fig. 5-b). Then, the cells developed gradually to filamentous mycelia. During 5-11 $\mathrm{hr}$, filamentous mycelia only and no spore-like cells were observed. Sporelike cells appeared again at $15 \mathrm{hr}$, and thereafter both the spore-like cells and filamentous mycelia were observed. Apparently the increase of meso- $\mathrm{A}_{2} \mathrm{pm}$ content during $0-5,19-24$ and $41-43 \mathrm{hr}$ is closely related to the synchronous elongation of the filamentous mycelia from the spore-like cells. From the information represented in Figs. 3-5, it is concluded that the $\mathrm{A}_{2}$ pm types are clearly related to the cell morphology.

\section{DISCUSSION}

In a submerged culture of $K$. setalba, both LL- and meso- $\mathrm{A}_{2}$ pm were detected in the whole mycelia, which included the two kinds of cells, spore-like cells and 


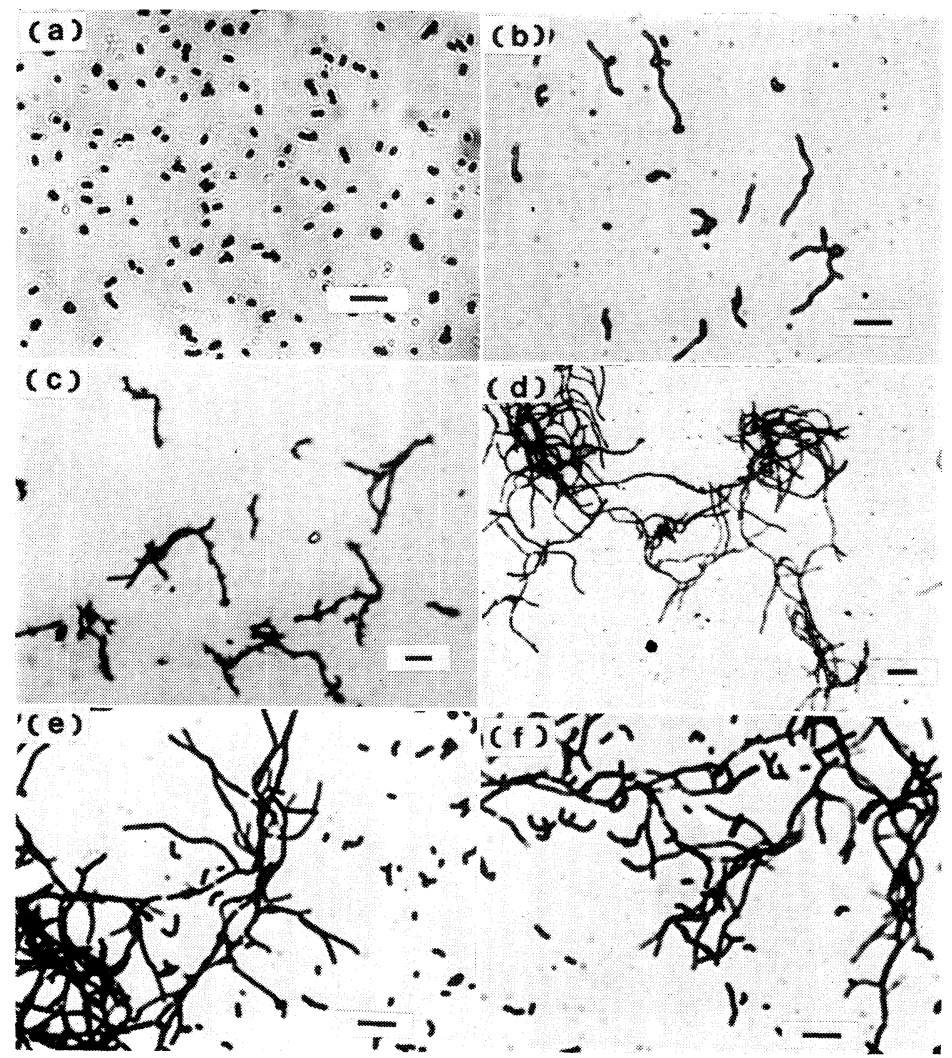

Fig. 4. Photomicrograph of $K$. setalba grown in a submerged culture at 0 (a), 1 (b), 5 (c), 11 (d), 15 (e) and $24 \mathrm{hr}$ (f).

The culture conditions are described in Fig. 3. The bar markers represent $10 \mu \mathrm{m}$.

filamentous mycelia (Fig. 1). The former contained $\mathrm{LL}_{-} \mathrm{A}_{2} \mathrm{pm}$, while the latter contained meso- $\mathrm{A}_{2} \mathrm{pm}$ (Fig. 2). The time course study indicates that the $\mathrm{A}_{2} \mathrm{pm}$ type clearly corresponds to the cell morphology (Figs. 3-5): only LL-A $\mathrm{A}_{2}$ pm was detected at $0 \mathrm{hr}$ when spore-like cells were inoculated as a seed culture. When mainly meso- $\mathrm{A}_{2}$ pm was detected during 5-11 hr, only filamentous mycelia were observed. The LL-A ${ }_{2} \mathrm{pm}$ content increased again after incubation for $11 \mathrm{hr}$, when spore-like cells were actively produced. It is of interest that the morphology in a submerged culture of $K$. setalba can be checked by analysis of the $\mathrm{A}_{2}$ pm type as shown in Fig. 3.

Comparing these results with the previous information that two kinds of $\mathrm{A}_{2}$ pm were detected separately in aerial and in vegetative mycelia (4), it was found that the cell morphology of $K$. setalba was apparently associated with the $\mathrm{A}_{2} \mathrm{pm}$ type: the two kinds of short cells, aerial-mycelium spores and submerged sporelike cells, contained LL-A ${ }_{2} \mathrm{pm}$, whereas the two kinds of long cells, vegetative and 


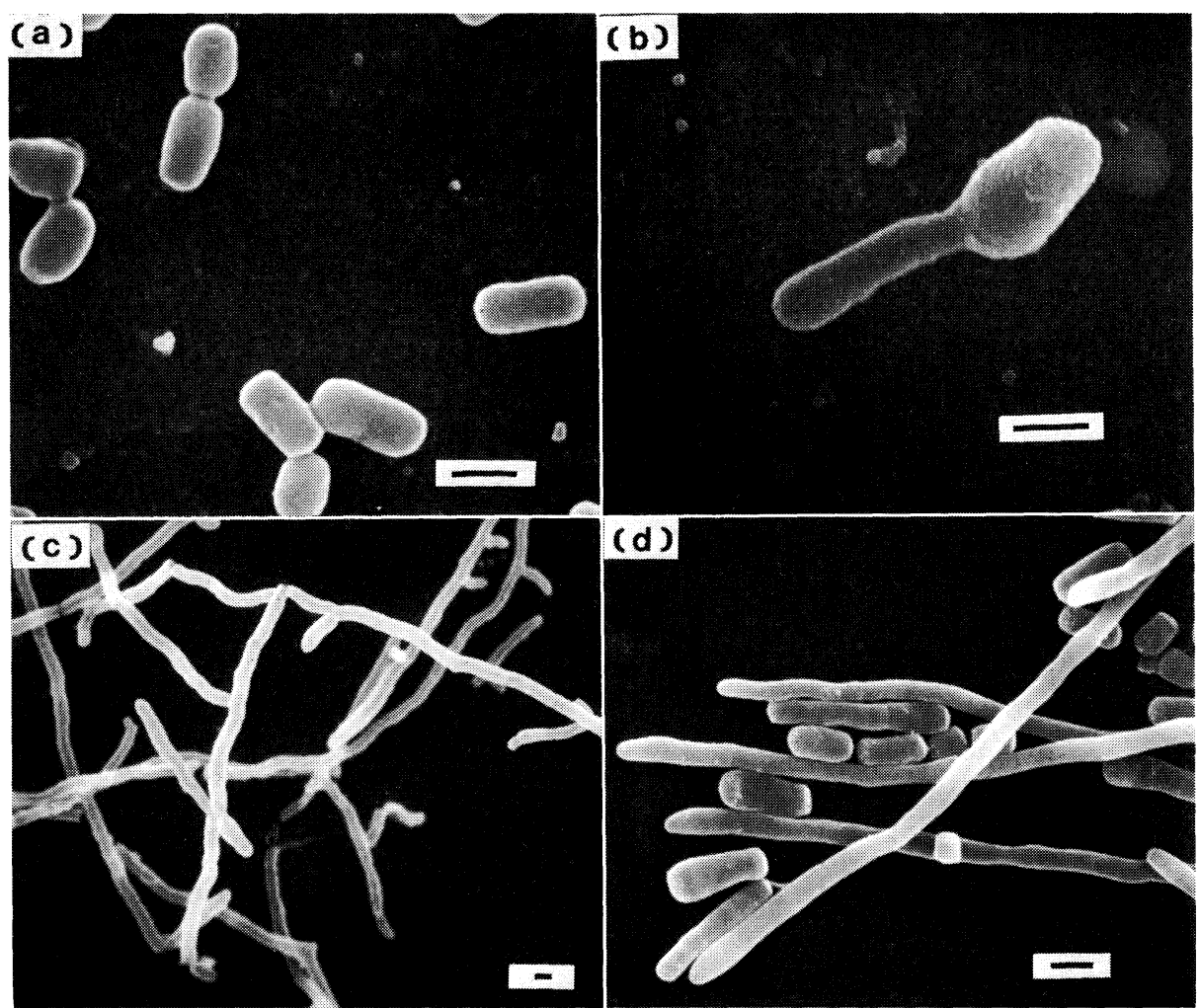

Fig. 5. Scanning electron photomicrograph of $K$. setalba grown in a submerged culture at 0 (a), 1 (b), 9 (c) and $15 \mathrm{hr}$ (d).

The culture conditions are described in Fig. 3. The bar markers represent $1 \mu \mathrm{m}$.

filamentous mycelia, contained meso- $\mathrm{A}_{2} \mathrm{pm}$.

Compared with the studies of spores grown on a solid culture, only a few descriptions of spores produced in a submerged culture of actinomycete strains have been reported (5). CARvajal (6), Wilkin and Rhodes (7) and ZaslavsKaya and ZHuKov (8) called these spores "submerged spores," "secondary mycelium spores" and "deep spores," respectively. Further it is known that some strains of the genus Micromonospora have different isomers of $\mathrm{A}_{2} \mathrm{pm}$ as cell-wall components (9). However, the relationship between morphology and $A_{2}$ pm type was not investigated until $K$. setalba was studied by the present authors. To our knowledge, our studies are the first investigations of the relationship in an actinomycete strain between the morphology and constituents of cells grown in submerged and on solid cultures.

It is not clear whether we can call the spore-like cell a true spore. But it appears to be so in the following regards. The spore-like cells resemble the aerialmycelium spores in morphology, in the presence of $\mathrm{LL}^{-} \mathrm{A}_{2} \mathrm{pm}$ and in resistance to 
ultrasonication $^{1}$. Also, in the submerged cultures, the spore-like cells are more resistant to lysozyme ${ }^{1}$ than the co-produced filamentous mycelia. To develop the studies further, we plan to investigate the constituent amino acids of the peptidoglycans in the four kinds of cells: the aerial and vegetative mycelia, the spore-like cells and the filamentous mycelia.

The authors wish to thank Dr. D. Nagaki of Kitasato University for his encouragement, Drs. Y. Tanaka and H. Tanaka of Kitasato University for their suggestions, and Miss R. Sato of Kitasato University for her assistance. This study was supported by a grant from the Waksman Foundation of Japan Inc.

\section{REFERENCES}

1) S. Ōmura, K. Otoguro, T. Nishikiori, R. Ōina and Y. Iwai, J. Antibiotics, 34, 1253 (1981).

2) M. P. Lechevalier and H. A. Lechevalier, Int. J. Syst. Bacteriol., 20, 435 (1970).

3) S. Ōmura, Y. Takahashi, Y. Iwai and H. Tanaka, J. Antibiotics, 35, 1013 (1982).

4) S. Ömura, Y. Iwai, Y. Takahashi, K. Kojima, K. Otoguro and R. Oiwa, J. Antibiotics, 34, 1633 (1981).

5) L. V. Kalakoutskit and N. S. Agre, Bacteriol. Rev., 40, 469 (1976).

6) F. Carvajal, Mycologia, 39, 426 (1947).

7) G. D. Wilkin and A. Rhodes, J. Gen. Microbiol., 12, 259 (1955).

8) P. L. Zaslavskaya and V. G. Zhukov, Mikrobiologiya, 45, 1035 (1976).

9) I. Kawamoto, T. OKa and T. Nara, J. Bacteriol., 146, 527 (1981).

1 Data are not shown. 